\title{
AOR
}

Selected Papers of \#AolR2021:

The 22nd Annual Conference of the

Association of Internet Researchers

Virtual Event / 13-16 Oct 2021

\section{PLATFORM AS NEW "DADDY": CHINA'S GENDERED WANGHONG ECONOMY AND PATRIARCHAL PLATFORMS BEHIND}

\author{
Xiaofei Han \\ Carleton University
}

\section{Introduction}

Wanghong, short for the Chinese term "wangluo hongren" ("internet red people"people who have gone viral online), refers to a particular stream of vocational Chinese internet celebrities that have acquired their celebrity online and have acute incentives through various models to liquidate such online influence by transforming followers into consumers (Han, 2020a). Centred around the popularity of wanghong and their enormous potential in monetizing such popularity, wanghong economy in China evolves distinctive platform-based commodification models ranging from virtual gifts, tipping, advertising, and more increasingly, e-commerce, with injection of capital from major platform companies like Alibaba and Tencent (Han, 2020a).

Through the framework of feminist political economy, this paper provides an explorative analysis of gender as a critical dimension of the prospering wanghong economy in China with special attention devoted to the e-commerce wanghong value chains. My analysis highlights the structurally embedded gender hierarchy of this platform business ecosystem. This research further connects the industrial, structural genderedness of wanghong economy with the cultural politics on popular livestreaming platform and examines how platform power has been associated with patriarchal order by looking into the specific case of updated meanings constructed around the word "baba" (daddy) that now is often used to refer to platforms. Ultimately, this paper seeks to combine the industrial analysis of wanghong economy as a prominent "platform economy" in contemporary China with its cultural dimensions and highlight the critical roles of major Chinese platform companies as not only new critical intermediaries in perpetuating the ongoing patriarchal system between the state and users but also active participants that aggressively profit from their construction of gendered wanghong economy value chains.

\section{Methodology}


This paper adopts a combined method of document analysis and online ethnography. It firstly conducted analysis of different types of corporate documents of eight leading Chinese platform companies: Alilbaba, Tencent, JD, Pinduoduo, Huya, Douyu, Douyin (Chinese TikTok also owned by ByteDance), and Kuaishou; and five top wanghong incubators: Ruhnn, Tisu, Chenfan, Qianxun, and Meiwan, in Chinese market, which together have laid down the early structure and set prototype of e-commerce wanghong value chains since mid 2010s. The documents covered include audited corporate reports and registration statements, published contracts and agreements, corporate official websites, third-party industrial reports, professional and official databases and aggregators, pertinent policy documents. The document analysis was also combined with a six-month online ethnography on three Chinese short video and livestreaming platforms that have a leading position in e-commerce wanghong sector-Douyin, Taobao Livestream, and Kuaishou, which enabled analyses of the cultural politics curated around wanghong in general and the specific case of referring host platform as "daddy" as well as the platform mechanisms behind that keeps perpetuating such patriarchal order between the platform and its users.

\section{Key Findings}

\section{Structural Gender Hierarchy}

Analysis shows that, firstly, as e-commerce has become one of the primary monetization means for wanghong economy in recent years, the embedded genderedness of women-led consumption that undergirds China's e-commerce platforms has been amplified with the coupling of wanghong industry of which the majority of wanghong are already women in the first place. Women are actively involved more than ever in the production and distribution networks at downstream of the e-commerce wanghong value chains as entrepreneurs and workers in Taobao villages $(\mathrm{H}$. Yu \& Cui, 2019). In contrast to the projection of wanghong economy as a new, progressive kind of platform economy that is by the women and for the women, there is a severe, structural gender hierarchy at the senior management level as revealed in Table 1. The female participation is slightly better for wanghong incubators yet it is still disproportionally low considering the majority of wanghong they incubated is female. This structurally embedded gender hierarchy of wanghong economy suggests how the asymmetric power relation in terms of decision-making and wealth distribution between big platforms and wanghong as platform labor and users has intertwined with gender, making major platforms the new patriarchal actors. Such structurally embedded genderedness of wanghong economy and the power hierarchy between participants and the patriarchal platforms is rendered explicit in the cultural politics and discursive construction around the term "baba" that is used to refer to popular short video and livestreaming platforms, Douyin in particular.

Table 1. Participation of Women in major platforms in wanghong economy as of 2020

\begin{tabular}{|l|l|l|l|}
\hline Category & Platform (company) & $\begin{array}{l}\text { Female board } \\
\text { director (\%) }\end{array}$ & $\begin{array}{l}\text { Female wanghong } \\
\text { incubated (\%) }\end{array}$ \\
\hline
\end{tabular}




\begin{tabular}{|c|c|c|c|}
\hline \multirow{4}{*}{$\begin{array}{l}\text { Major internet } \\
\text { Companies and e- } \\
\text { commerce } \\
\text { platforms }\end{array}$} & Alibaba & $31.8 \%$ & I \\
\hline & Tencent & $11 \%$ & I \\
\hline & JD & $10 \%$ & I \\
\hline & Pinduoduo & $0 \%$ & l \\
\hline \multirow{5}{*}{$\begin{array}{l}\text { Short video and } \\
\text { livestreaming } \\
\text { platforms }\end{array}$} & Huya & $9 \%$ & I \\
\hline & Douyu & $9 \%$ & l \\
\hline & Douyin (ByteDance) & $0 \%$ & l \\
\hline & Kuaishou & $0 \%$ & I \\
\hline & $\begin{array}{l}\text { Taobao Livestream } \\
\text { (Alibaba) }\end{array}$ & $31.8 \%$ & I \\
\hline \multirow{5}{*}{$\begin{array}{l}\text { Leading e- } \\
\text { commerce } \\
\text { Wanghong } \\
\text { Incubators }\end{array}$} & Ruhnn & $8.3 \%$ & $100 \%$ \\
\hline & Qianxun & $0 \%$ & $89 \%$ \\
\hline & Meiwan & $10 \%$ & Not disclosed \\
\hline & Tisu & $20 \%$ & $93 \%$ \\
\hline & Chenfan & $60 \%$ & $100 \%$ \\
\hline
\end{tabular}

Sources: Author's compilation of data extracted from corporate annual reports, corporate Registration Statements prepared for the Securities and Exchange Commission in U.S. stock market and/or Hong Kong stock market, enterprise announcements and official websites, and National Enterprise Credit Information and Publicity System of People's Republic of China

\section{Platform as New Daddy}

Increasing number of Wanghong give their host platforms, Douyin in particular, the nickname of "baba" (daddy) in their daily communication processes with audiences. Two key themes are identified with the daddy narrative circulated on the platform Douyin (Dou baba). Firstly, platform's algorithms are perceived to be fair and reliable and it is the users' responsibility to obey the rules of the platform (such as to maintain certain frequency and length for livestreaming sessions in order to be qualified to be recommended by the platform to larger pool of users) and the platform will reward obedient users with more visibility to the account. Secondly, platform like Dou baba is often glorified as the ultimate savior for streamers' as it provides a better alternative for making a livelihood. Many streamers perceive Douyin as a shelter so they do not have to work twelve hours a day in a factory, given that many of them now are from semirural and rural areas of China, as more local governments provide support to the ecommerce wanghong business as an important way to raise local income and create more jobs. Dou baba further provides tremendous opportunities for streamers to become successful, which indeed clings into the traditional father figure, especially in Chinese society: streamers just need to obey and work hard towards father's expectation to exchange for financial returns. Such discursive construction of platformas-daddy echoes the structural genderedness of wanghong economy and the marginalization of streamers in getting involved at higher level of wanghong economy to represent their own benefits. It shows that wanghong are usually very aware of the asymmetric power relation between major platform companies and themselves but rarely find it problematic. In particular, through the daddy narrative, the exploitative nature of platforms is not only covered but further legitimized, naturalized, and even glorified, which have imposed further challenges for forming possible resistance from the participants. 